\section{El paso de Asclepio a Cristo en la primera literatura cristiana*}

\author{
Juan Carlos Alby**
}

RECIBO: 24-07-14 - APROBACIÓN: 27-11-14

Resumen: Se ilustra la transición de la devoción a Asclepio hacia el culto cristiano, atestiguada tanto por los reemplazos de los santuarios como por la permanencia de técnicas médicas reorientadas desde el dios griego de la medicina hacia Cristo. En tal sentido, se destaca la vigencia de los sueños de incubación entre los primeros cristianos y en la literatura cercana al antiguo Israel. Se analiza también la reacción de los padres de la Iglesia en los escritos que denuncian la infiltración del paganismo helénico en la fe cristiana.

Palabras clave: Asclepio, Cristo, sueños de incubación, literatura patrística, suplantación.

PARA CITAR ESTE ARTÍCULO:

Alby, Carlos. "El paso de Asclepio a Cristo en la primera literatura cristiana." Theologica Xaveriana 179 (2015): 185-208. http://dx.doi.org/10.11144/ javeriana.tx65-179.pacp

\section{Moving from Asclepius to Christ in the Early Christian Literature}

Aвstract: It describes the transition from the devotion to Asclepius towards the Christian cult, represented by the replacement of the sanctuaries and by the medical techniques reoriented from the Greek god of Medicine towards Christ. In that sense, it emphasizes on the validity of the dreams of incubation among the first Christians and on literature close to ancient Israel. It also analyzes the reaction of the Fathers of the Church to the writings that denounce the infiltration of Hellenic paganism into the Christian faith.

KeY words: Asclepius, Christ, encubation dreams, patristic literature, Impersonation.

\section{A passagem de Asclépio a Cristo na primeira literatura cristã}

Resumo: Ilustra-se a transição da devoção a Asclépio ao culto cristâo, testemunhada tanto pela substituição dos santuários como pela permanência de técnicas médicas reorientadas do deus grego da medicina para Cristo. Nesse sentido, se destaca a vigência dos sonhos de incubação entre os primeiros cristãos e na literatura próxima ao antigo Israel. Analisa-se também a reação dos pais da Igreja nos escritos que denunciam a infiltração do paganismo helênico na fé cristã.

palavras-Chave: Asclépio, Cristo, sonhos de incubação, literatura patrística, suplantaçáo.

\footnotetext{
* El presente trabajo fue realizado en el marco del Proyecto de Investigadores Formados "La Biblia y el helenismo en la formación de la cultura occidental", financiado por la Secretaría de Ciencia y Técnica de la Universidad Católica de Santa Fe, UCSF, Argentina.

${ }^{* *}$ Doctor y Licenciado en Filosofía, Universidad Católica de Santa Fe; Bioquímico, Universidad Nacional del Litoral, Santa Fe; Administrador en Salud, Escuela Superior de Sanidad "Dr. Ramón Carrillo". Profesor titular, Universidad Nacional del Litoral, UNL; profesor titular, Universidad Católica de Santa Fe; docente de la Facultad de Ciencias Médicas de la UNL. Correo electrónico: jcalby@hotmail.com
} 


\section{Introducción}

Durante los tres primeros siglos de la era cristiana, en el periodo que recibe la denominación historiográfica de "Antigüedad tardía", la medicina se hallaba cimentada en las intuiciones fundamentales de Hipócrates y de la escuela metódica fundada por Themisón de Laodicea, a las cuales se agregaron en el siglo II las prácticas quirúrgicas de Galeno, iniciador por excelencia del pensamiento anatómico. La práctica médica oscilaba entonces entre la especulación teorética, propia de la escuela de Cos, y la empírica característica de los metódicos.

El surgimiento del cristianismo, que pregonaba el Reino de Dios como núcleo central de su mensaje, aportó al acto médico un nuevo elemento que, si bien mutatis mutandis se encontraba presente en las tradiciones que remontaban hasta el mismo Asclepio, adquieren en el horizonte cristiano el estatuto de "signos" (semeia) de la presencia del Reino de los Cielos en la temporalidad humana. De esta manera, lo que se conoce como "milagro" irrumpe en la téchne iatriké de la época con características diferentes de las de los "sueños de incubación" de los seguidores de Asclepio.

Es posible extraer de la primera literatura cristiana canónica y apócrifa, de los escritos del judaísmo posbíblico y de la filosofía helénica, ideas fundamentales sobre el dinamismo cósmico y la centralidad del hombre como campo de convergencia de esas fuerzas conjuradas por el que realiza la curación.

\section{La devoción a Asclepio en la medicina antigua}

En cuantiosos documentos del periodo greco-romano hay constancias suficientes sobre un debate acerca de si los dioses estaban o no implicados en la sanación humana y, de ser así, por qué medios. Asclepio era considerado a la vez como el patrono de los médicos y como el dios benéfico que actuaba para sanar a los suplicantes. Por otra parte, quienes pretendían realizar milagros eran acusados por sus detractores de practicar magia, del mismo modo en que los magos invocaban los nombres de sus dioses sanadores.

Como señala H. Rivers, la medicina primitiva perseguía el mismo fin que la religión, es decir, salvaguardar la vida, por lo cual utilizaba los mismos medios, pues -en los comienzos- medicina y religión formaban parte de la misma disciplina, de la que también la magia era tan solo otro apartado. ${ }^{1}$

${ }^{1}$ Ver a Rivers, Medicine, Magic and Religion, vii. 
En efecto, los primeros en ejercer la medicina atribuyeron el origen de su arte a los dioses, especialmente a Asclepio, a pesar de que -según la leyenda- el dios había sido fulminado por un rayo por haberle devuelto la vida a un individuo. En la isla de Cos, donde había un santuario dedicado a Asclepio al que acudían muchos pacientes que luego dejaban allí sus testimonios en favor del poder curativo del dios, nació el fundador de la tradición médica griega, Hipócrates.

Según Plinio, Hipócrates se aprovechó del incendio del templo de Asclepio estableciendo en Cos un centro médico que convirtió la medicina en un saber lucrativo. No obstante, el mismo autor admite que "con gran distinción", Hipócrates había sentado las normas para la práctica de la medicina, incluidos abundantes consejos sobre el uso de las hierbas, aunque su tradición "degeneró gradualmente hasta quedar reducida a meras palabras y charlatanerías", más interesada en las lecturas que en la búsqueda de plantas medicinales. ${ }^{2}$

El culto a Asclepio irrumpe con gran fuerza en los finales de la época arcaica, cuando descollaba la figura del "héroe médico", prerrogativamente encarnada en Apis el iatrómantis ("médico adivino"), fundador de Apia en la Argólide. Hasta entonces, Asclepio no era incluido entre los dioses curadores, cuya dynamis particular era la iatriké ("curativa"), lo cual puede corroborarse en el canto V de la Ilíada, según el cual el médico de los dioses era Paeion ${ }^{3}$ y, junto a él, Apolo, con quien se fundió en el ritual. ${ }^{4}$ Tampoco los hijos de Asclepio, los médicos Podalirio y Macaón, habían sido divinizados en los poemas homéricos. ${ }^{5}$

${ }^{2}$ Kee, Howard Clark. Medicina, milagro y magia en tiempos del Nuevo Testamento, 20.

3 "Y las toleró también el ingente Hades cuando el mismo hijo de Zeus, que lleva la égida, disparándole en Pilo veloz saeta, lo entregó al dolor entre los muertos con el corazón afligido, traspasado de dolor -pues la flecha se le había clavado en la robusta espalda y abatía su ánimo- fue al palacio de Zeus, al vasto Olimpo, y como no había nacido mortal, lo curó Paeion, esparciendo sobre la herida drogas calmantes." (Homero, Ilíada V, 401). Atacado por Diomedes con su propia lanza y con la ayuda de Palas Atenea, el dios Ares, herido y doblegado por el dolor, acudió a Zeus, quien ordenó a Paeion que lo curara: "Paeion le sanó, aplicándole drogas calmantes; que nada mortal en él había: como el jugo cuaja la blanca y líquida leche cuando se le mueve rápidamente con ella, con igual presteza curó al furibundo Ares, a quien Hebe lavó y puso lindas vestiduras. Y el dios se sentó al lado de Zeus Cronión, ufano de su gloria." (Homero, Ilíada. V, 900).

${ }^{4}$ Véase la nota 22 de Marta Alesso y Alejandra Regúnuga a Homero, Ilíada, V, 400ss., 172.

5 “¡Oh Néstor Nelida, gloria insigne de los aqueos! Ea, sube al carro, póngase Macaón junto a ti, y dirige presto a las naves los solípedos corceles. Pues un médico vale por muchos hombres, por su pericia en arrancar flechas y aplicar drogas calmantes. Dijo; y Néstor, caballero gerenio, no dejó e obedecerle. Subió al carro, y tan pronto como Macaón, hijo del eximio médico Asclepios, le hubo seguido, picó con el látigo a los caballos y estos volaron de su grado hasta las cóncavas naves..." (Homero, Iliada. XI, 511-520, 323). 
El culto a Asclepio comienza en Tricca de Tesalia, de donde se extiende por la Grecia central y el Peloponeso. El traslado de su santuario desde Epidauro ${ }^{6}$, en 420 a.C., hasta Roma, en la isla Tiberina, hizo escala en distintos sitios, tales como Atenas, el Pireo y la isla de Cos -antes de la instalación en esta última de una escuela de medicina técnica- y estuvo rodeado de portentos, según relatos de Livio y de Ovidio. ${ }^{7}$

Los milagros de Asclepio acontecían en la enkoímesis o incubatio, sueños durante los cuales los enfermos, exigidos a pasar una noche completa en el ábaton, zona baja del santuario rodeada por un triple círculo de muros y a la que se accedía por varias puertas, eran visitados por el dios en sus manifestaciones oníricas o en la presencia de sus sacerdotes, así como de los perros y serpientes sagradas.

La presencia de perros en el edificio de incubación en el que dormían los suplicantes se debe a la leyenda según la cual el Asclepio niño había sido cuidado por un perro y amamantado por una cabra. ${ }^{8}$ La serpiente formaba parte de la estatua de

\begin{abstract}
${ }^{6}$ El Asklepieion de Epidauro se destaca entre los lugares paganos a los que los enfermos acudían. Fue descubierto por P. Kavvadias durante sus excavaciones (1881), cuyos resultados fueron publicados en Atenas doce años más tarde bajo el título de Les fouilles d'Epidaure. Tales resultados se refieren principalmente a tres estelas completas y otra fragmentaria en las que se consignan los iamata, elenco de setenta curaciones milagrosas obradas por Asclepio. Los trabajos de Kavvadias fueron precedidos por la obra pionera de H. Meiborn en el siglo XVII, De incubatione in fanis deorum medicinae causa olim facta, Helmstadt, 1659. Los experimentos de F. J. Mesmer con el magnetismo animal y el sonambulismo inspiraron diversos trabajos que comparaban la psicología, que en aquellos tiempos estaba en ciernes, con las curaciones producidas por la incubatio de los Asklepieia, tratando de conferirles a estas últimas una explicación científica; pero en cuanto a rigor metodológico y profundidad en el análisis filológico de los ritos propios de la incubatio en la Antigüedad clásica, ocupa un sitial de privilegio el trabajo de L. Deubner, De Incubatione (Berlín, 1900), que en su Capítulo IV se ocupa del estudio de este fenómeno en el cristianismo. Una lista muy importante de bibliografía sobre el tema puede encontrarse en López Salvá, "El sueño incubatorio en el cristianismo oriental", 147-188 (aquí, 148, No. 3).
\end{abstract}

${ }^{7}$ Según relatos de Livio (Historia de Roma desde la fundación de la CiudadX, 47, 11) y de Ovidio (Metamorfosis XV, 625-744), el dios había dado su conformidad para el traslado de su centro de culto, lo cual fue corroborado por la presencia de una serpiente que, tras salir del santuario, subió a bordo del barco que transportaba la estatua de Asclepio y se mantuvo expectante mientras la nave remontaba la corriente del Tíber, hasta dar indicios inequívocos de cuál debía ser su nueva morada, a saber, la isla Tiberina. Ver a Kee, Medicina, milagro y magia en tiempos del Nuevo Testamento, 105ss.)

${ }^{8}$ Según esta tradición destinada a explicar por qué Asclepio era el gran dios de Epidauro, que difiere de la versión más corriente sobre su nacimiento, aceptada y difundida por Píndaro, un ladrón llamado Flegias habría visitado el país para informarse acerca de sus riquezas y de cómo apoderarse de ellas. Lo acompańaba su hija, quien en el curso del viaje fue seducida por Apolo y dio a luz un nińo en tierras de Epidauro, al pie del monte Mirtio. Luego de abandonarlo, una cabra lo amamantó y un perro lo cuidó hasta cuando el pastor Arestanas, quien era el dueño de los animales, encontró a la criatura y quedó admirado por la aureola que la rodeaba. No se atrevió a recogerla por temor al misterio que tal fenómeno suponía, por lo cual el niño continuó solo su destino divino. Ver a Grimal, Diccionario de mitología griega y romana (voz "Asclepio"), 56. 
Asclepio construida con oro y marfil, que Pausanias describe con ocasión de su visita a Epidauro, en el siglo II. ${ }^{9}$ Simbolizaba la capacidad de Asclepio de renovar el cuerpo, haciéndolo pasar de la salud a la enfermedad, así como la serpiente muda su piel. ${ }^{10}$

El modo de la teofanía de Asclepio es atestiguado por Aristófanes (450-338 a.C.), quien menciona una ocasión en que los que acudían en busca de la ayuda del dios durmieron durante una noche en el santuario. En un caso, el dios actuó como médico, según las recetas de la medicina técnica, aplicando un emplasto en los ojos de un hombre afectado de la vista. El otro paciente, llamado Pluto, cuyo nombre da el título a la obra del gran comediante, fue asistido por Asclepio bajo la forma de serpientes que lamieron sus párpados hasta que, obrada la curación, se alejaron en su reptar sigiloso, perdiéndose en la oscuridad de los patios interiores del santuario. ${ }^{11}$

En este relato puede apreciarse la versatilidad de la acción del dios curador, quien actúa según la medicina técnica y al mismo tiempo obra milagros; pero en cualquiera de los casos, la curación era entendida como resultado de la intervención directa del dios y no de la virtud de drogas o procedimientos médicos.

\section{Los orígenes de la incubatio}

Los orígenes de la incubatio se remontan más allá de la divinidad panhelénica que nos ocupa y llegan hasta el Imperio Mesopotámico. Heródoto describe un santuario de bronce que todavía existía en sus días, consagrado a Zeus Belo o Bel-Marduk, dios supremo del sincretismo religioso babilónico y señor del destino y de la creación, cuyo templo era el Esaglia en Babilonia. En ese lugar no se levantaba ninguna estatua y nadie podía permanecer allí de noche, con excepción de una mujer del lugar, a quien el dios -según cuentan los caldeos que son los sacerdotes de esa divinidad- elige entre todas.

Esos mismos sacerdotes sostienen -aunque para mí sus palabras no son dignas de crédito- que el dios en persona visita el templo y que descansa en la cama, al igual que ocurre, al decir de los egipcios, en Tebas (pues allí también se da

\footnotetext{
9 "La arboleda sagrada de Asclepio tiene mojones a su alrededor en todas direcciones. Dentro de ese recinto, no muere ningún hombre y ninguna mujer da a luz [...]. Todo el mundo, ya sea epidaurio o extranjero, consume su sacrificio dentro de las lindes [...]. La estatua de Asclepio es la mitad de grande que la del Zeus Olímpico de Atenas y está hecha de marfil y oro. Está sentado en el trono con un báculo, con una mano sobre la cabeza de la serpiente y un perro tumbado junto a él." (Pausanias. Descripción de Grecia II, 27, 1-3, 205).

${ }^{10}$ Ver a Cox Miller. Los sueños en la antigüedad tardia. Estudios sobre el imaginario de una cultura, 138.

${ }^{11}$ Aristófanes. "Pluto", Acto III, escena 2, 457.
} 
el caso de una mujer que duerme en el templo de Zeus tebano; y aseguran que esas dos mujeres no mantienen relaciones con hombre alguno); y lo mismo hace en Patara de Licia, la profetisa del dios cuando este acude, pues en realidad allí no siempre funciona el oráculo. Ahora bien, cuando el dios acude, entonces se encierra con él por las noches en el templo. ${ }^{12}$

El testimonio de Heródoto resulta iluminador respecto de la práctica de los ensueńos, pues no solo se limita a Babilonia sino extiende su registro a Egipto, en particular en el templo de Amón en Karnak, y a Licia, donde funcionaba el oráculo de Apolo solo cuando este dios acudía a pasar el invierno, ya que al verano lo pasaba en Delos. ${ }^{13}$

También la tradición de Ugarit, del siglo XIII a.C., nos revela dos ritos de incubatio: uno, en el poema épico de Anat y Aqhatu, en el que un juez justo llamado Daniilu fue al templo de Baal para suplicarle que le concediera un hijo; después de permanecer siete días ahí, hizo preparar un banquete para el dios cuando este apareciera en sus sueños.

[Entonces Daniilu el] Rapai, Inmediatamente el Prócer [Harnami], revestido a los dioses alimentó, [revestido dio a beber] a los santos;

se quitó [su atuendo, se echó encima] y se acostó, se quitó [su veste] y se echó a dormir.

Pasó un día y otro:

[revestido] a los dioses Daniilu, [revestido a los dioses] alimentó.

Revestido [dio a beber a] los santos.

Un tercer y cuarto día pasó:

[revestido] a los dioses Daniilu, revestido [a los dioses] alimentó, revestido dio a beber a los [santos].

Un quinto y sexto día pasó:

revestido [a los dioses] Daniilu, revestido a los dioses alimentó, [revestido] dio a beber a los santos,

\footnotetext{
${ }^{12}$ Heródoto. Historia I, 182, 239ss.

${ }^{13}$ Ver a Virgilio. Eneida IV, 143ss., 74.
} 
se quitó su atuendo [Daniilu],

se quitó su atuendo, se echó encima y se acostó,

[se quitó] su veste y se echó a dormir.

Y, ¡mira! Al séptimo día

Se acercó, [sí], Ba'lu en su benevolencia:

“QQué miserable estás, Daniilu el Rapai,

quejumbroso, el Prócer Harnami,

el que no tiene hijos como sus hermanos,

ni descendencia como sus parientes!

¡Que pueda tener un hijo como sus hermanos

y descendencia como sus parientes,

(el que) revestido a los dioses alimenta,

revestido da de beber a los santos!

Bendícelo, ¡oh Toro Ilu!, padre mío,

confórtalo, ¡oh Creador de las criaturas!

Y haya un hijo suyo en (su) casa,

descendencia en el palacio..."14

El otro rito de incubatio es en el que el rey Kirta se entrega al sueño sagrado en una situación de desamparo minuciosamente descrita. El rey que ha sufrido la destrucción de su familia, se retira a su cámara y, en medio de llantos y súplicas, es dominado por un sueño profundo en el que recibe la teofanía.

Entró en su cámara a llorar,

repitiendo sus quejas (y) derramó lágrimas.

Corrían sus lágrimas

como siclos al suelo,

como pesas de a cinco sobre el lecho.

En su llanto quedó adormecido,

en su llanto tuvo un desvanecimiento,

el sueño le venció y se acostó,

el desvanecimiento, y se acurrucó.

Y en su sueño Ilu descendió,

en su visión el Padre del hombre.

Y se acercó preguntando a Lirta:

14 "Epopeya de Aqhatu" (KTU 1, 17 I, 1-15), en Del Olmo Lete, Mitos y leyendas de Canaán según la tradición de Ugarit, 367ss. 
“QQué (tiene) Kirta que llora,

Que gime el Apuesto servidor de Ilu?”15

La mántica onírica se encuentra documentada por Heródoto con particular atención a los héroes ctónicos, tales como Anfiarao en Oropos ${ }^{16}$ y Trofonio en Lebadea. ${ }^{17}$ Los que visitaban sus tumbas eran impulsados por motivos adivinatorios pero también por enfermedades que eran curadas por las visitas de estos héroes durante sus sueños.

Pausanias, por su parte, señala la necesidad de purificación previa a la consulta a Anfiarao. La misma consistía en una jornada de ayuno, la abstención de vino durante tres días y el sacrificio al héroe de un carnero, sobre cuya piel se acostaban los visitantes para aguardar la manifestación onírica de Anfiarao. ${ }^{18}$

Hacia el final de la época helenística y romana, el carácter filantrópico y afable de Asclepio hizo fácil su asociación con otras divinidades curadoras, tales como Isis y Serapis. Su simpatía por los esclavos y enfermos, le valió el título de sotêr, "salvador", "conservador", lo que motivó la reacción por parte de los padres de la Iglesia, preocupados por la similitud entre el dios y la figura de Cristo: tanto uno como otro eran hijos de un dios, curaron enfermos, devolvieron la vida a un muerto y, condenados a morir, ambos ascendieron a los cielos y se mostraron a sus fieles en forma corpórea.

La fuerza del culto a Asclepio queda demostrada por el hecho de que alcanzó su máxima difusión en el siglo IV a.C., al mismo tiempo en que se produjo el más amplio desarrollo de la medicina hipocrática. En efecto, el nombre de Hipócrates había eclipsado a todos los demás en el siglo $\mathrm{V}$ en que los médicos de Cos -que se llamaban a sí mismos "Asclepíadas"- habían alcanzado enorme fama. Hacia el 366 o 365 a.C., cuando se había fundado una nueva capital en Cos, se erigió al mismo tiempo un santuario a Asclepio que más tarde se fue ampliando de manera suntuosa. ${ }^{19}$

15 “Epopeya de Kirta” (KTU I, 14 I 26-37), en Del Olmo Lete, Mitos y leyendas de Canaán según la tradición de Ugarit, 290ss.

${ }^{16}$ Las excavaciones de 1884 en Oropos han demostrado que este era el lugar en el que se practicaba la incubatio, según una inscripción publicada por Wilamowitz, en la que se detallan ciertas reglas para el orden del templo. Ver a López Salvá, "La medicina sacra en la Antigüedad", 23-45.

${ }^{17}$ Ver a Heródoto, Historia I, 46, 52 y VIII, 134, 121 y 126.

18 "Creo que Anfiarao se dedicaba sobre todo a la interpretación de los sueños; y es claro que, cuando fue considerado dios, instituyó la adivinación por los sueños. Es costumbre que el que viene a consultar el oráculo de Anfiarao debe en primer lugar purificarse. La purificación consiste en hacer sacrificios al dios, y no solo a él, sino a todos los que tienen en el altar sus nombres. Una vez hecho esto, sacrifican un carnero, extienden su piel y duermen sobre ella, aguardando la revelación de un sueño." (Heródoto, Historia I, 34, 5, 99ss.).

${ }^{19}$ Ver a Burkert, Religión griega arcaica y clásica, 290. 
Lejos de ser eclipsada por el auge de lo que podría considerarse como medicina filosófica o racionalista, la devoción a Asclepio se desplegó con énfasis notable. La razón de este crecimiento paralelo de dos modalidades médicas que, a primera vista, podrían resultar contradictorias, se funda en la posibilidad de que los griegos hayan experimentado una sensibilidad particular por el arquetipo del "curador", al que consolidaron en la sacralización de Asclepio. ${ }^{20}$

Incluso - como veremos a continuación- la aparición del cristianismo no logró desplazar la práctica de los sueños de incubación, firmemente instalados en el horizonte del paganismo greco-romano. La incubatio se desplegaba en doble registro. Por un lado, revelaba una faz religiosa y popular en la que los enfermos que la practicaban, impulsados por los instintos inconscientes de curación, no reparaban en las razones últimas de sus actos. Por otra parte, presentaba un aspecto técnico semejante al de ciertas prácticas de la medicina actual, que se orientan a la exploración de regiones desconocidas del inconsciente humano con el fin de lograr la curación de enfermedades desahuciadas por los médicos. ${ }^{21}$

Entre las distintas prácticas adivinatorias paganas, los sueños fueron la única admitida por la Iglesia cristiana en virtud de su base bíblica, ya que el mismo Pedro había citado en sermón de Pentecostés la profecía de Joel: "Vuestros ancianos tendrán sueños y vuestros jóvenes verán visiones." ${ }^{22} \mathrm{El}$ interés por los sueños, por parte de la Iglesia cristiana, se orienta a conferirles un sentido teológico. De ahí que la inclusión de los mismos en la literatura cristiana fuera considerada por Hanson como la teologización de su mensaje. ${ }^{23}$

No obstante -como advierte Siniscalco-, hay una línea de demarcación entre el sueño pagano y el sueño cristiano, ya que este último no solo respondía a fines personales sino también a una conciencia misionera y eclesial, lo que otorgaba a la experiencia onírica cristiana un horizonte particular. ${ }^{24}$

\footnotetext{
${ }^{20}$ Ver a Gil Fernández, Therapeia. La medicina popular en el mundo clásico, 43.

${ }^{21}$ Ver a Teja, "Cultos y ritos terapéuticos cristianos en la hagiografía de Oriente (siglos IV-VI)", 129-159.

$22 \mathrm{Jl} 2,28$, citado en Hch 2,17. Ver a Dodds, Paganos y cristianos en una época de angustia. Algunos aspectos de la experiencia religiosa desde Marco Aurelio a Constantino, 63.

${ }^{23}$ Hanson, "Dreams and Visions in the Graeco-Roman World and Early Christianity", 1395-1427 (aquí: 1425).

${ }^{24}$ Ver a Siniscalco, "Pagani e christiani antichi di fronte all'esperienza di sogni e visioni”, 156.
} 


\section{La controversia entre Cristo y Asclepio}

Si bien la comparación entre Cristo y Asclepio es la que interesa para el presente trabajo, es preciso destacar que ella no es la única que los padres de la Iglesia hacen, pues otros dioses y héroes del panteón griego también son sometidos a tal cotejo en algunos otros aspectos. Los padres utilizaron la metáfora del "Cristo médico" para reaccionar contra los dioses curadores, en particular contra Asclepio, en los siglos II y III, y contra los cultos orientales de Isis, Mitra y Serapis, en el siglo IV. ${ }^{25}$

Durante el siglo II, el culto a Asclepio se encontraba en plena vigencia, como se desprende de la lectura de Elio Arístides en sus Discursos sagrados, compuestos aproximadamente entre 165 y 175. Las experiencias oníricas del sofista resultaban conocidas por sus amigos, entre quienes contaban eminentes hombres de letras y funcionarios de altos cargos, en el santuario de Asclepio, que habían intentado persuadirlo a que hablase o escribiese sobre los sueńos:

Rehuyendo lo imposible, nunca me dejé persuadir por ninguno de mis amigos que me rogaron o presionaron alguna vez para que se los contara de viva voz o los pusiera por escrito. Pues me parece que lo que se me pedía es lo mismo que si, tras haber atravesado todo el mar sumergido, se me obligase a rendir cuentas del número de olas con las que me encontré, de qué clase de aguas había probado en cada una de ellas y de cómo fue mi salvación. ${ }^{26}$

Más adelante, en el Discurso XLVIII, afirma que el dios le ordenó realizar un registro de sueños:

Encontraba innumerables excusas para ello, tanto ante Dios como ante mis propios amigos, que siempre me estaban pidiendo que los narrase o que compusiese una obra sobre ellos. Pero ahora que han pasado tantos años y aquellos momentos quedan lejos algunas visiones oníricas nos están obligando a publicarlos de alguna forma. En verdad tengo que decir que ya desde el principio Dios me ordenó levantar un registro de sueńos. ${ }^{27}$

Asclepio comienza por ser un consejero médico, pero muy pronto va extendiendo su ayuda a toda la vida de Arístides, pues lo aconseja sobre sus lecturas, le inspira ideas sorprendentes, le dicta el párrafo inicial de un discurso o el primer verso de un

\footnotetext{
${ }^{25}$ Ver a Vannier, "L'image du Christ médecin chez les Pères", 525-553 (aquí: 529).

${ }^{26}$ Elio Arístides, "Discursos sagrados” XLVII, 2, 280.

${ }^{27}$ Ibid., XLVIII, 1-2, 310.
} 
poema, e incluso le enseña el futuro bajo la forma de previsiones del tiempo a corto plazo. En un sueño, Arístides se ve ante su propia estatua y, de repente, su figura se cambia en la de Asclepio. ${ }^{28}$ Como afirma Dodds, la relación de Arístides con Asclepio es un caso singular de simbiosis entre hombre y Dios tanto por su intensidad como por su duración y revela la creencia de su época. ${ }^{29}$

Sin negar la efectividad de los milagros de Asclepio, los padres instan a sus lectores a confiar más en el carácter divino de los milagros de Cristo, atribuyéndoles a los del dios pagano un origen demoníaco, además del reproche por aceptar una retribución como pago por sus servicios, según lo dicho por Platón:

Y pensaban que la vida de alguien enfermizo e intemperante por naturaleza no sería de provecho ni para sí mismo ni para los demás, por lo cual no se le debía aplicar el arte de la medicina ni llevar a cabo tratamiento alguno, ni aunque fuese alguien más rico que Midas.

-Muy ingeniosos fueron los hijos de Asclepio, según lo que dices.

-Es lo que corresponde a la realidad, aunque los autores de tragedias ${ }^{30} \mathrm{y}$ Píndaro $^{31}$ no compartan nuestra opinión y digan que Asclepio, hijo de Apolo, fue seducido con oro para que curase a un hombre rico que estaba por morir, por lo cual fue abatido por un rayo. ${ }^{32}$

Justino Mártir, en su gran Apología compuesta en dos partes hacia el 150 d.C. y dirigida a dos emperadores para la autoafirmación de la enseñanza cristiana frente a la filosofía gentil, señala que la doctrina cristiana sobre el Verbo generado y ascendido al Cielo reclama compararse a los relatos sobre Zeus, Asclepio y Hermes. Esto nos indica que ya se había instalado en el ambiente intelectual del siglo II la comparación de Jesús como sanador con el dios Asclepio: "En fin, que [Jesús] sanara a cojos y paralíticos y enfermos de nacimiento, resucitara muertos, también en esto pareció que decimos cosas semejantes a lo que se cuenta haber hecho Asclepio." ${ }^{3}$

\footnotetext{
${ }^{28}$ Ibid., XLVII, 17, 286.

${ }^{29}$ Dodds, Paganos y cristianos en una época de angustia, 70.

${ }^{30}$ Ver a Esquilo, Agamenón, 1022, 199; Eurípides, Alcestis 3-4, 13.

${ }^{31}$ Ver a Píndaro, "Pítica” III, 55, 106.

32 Platón, República III, 408b-c, 188.

${ }^{33}$ Justino, I Apología 22, 6, citado por Ruiz Bueno, Padres apologetas griegos (siglo II), 206.
} 
Respecto de la ascensión de Cristo, el filósofo cristiano afirma que tal relato no debería resultarles extraño, ya que los relatos de los griegos afirman que Asclepio, quien fue médico, después de haber sido fulminado subió al cielo ${ }^{34}$.

En diálogo con el judío Trifón, Justino califica las curaciones de Asclepio con imitaciones diabólicas y apropiaciones indebidas de la prerrogativa de Cristo anunciada por los profetas: "Y, en fin, cuando nos presenta a Asclepio resucitando muertos y curando las demás enfermedades, ¿¿no diré que también en esto quiere imitar el diablo las profecías sobre Cristo?"35

Por su parte, Clemente de Alejandría señala la similitud entre un epigrama del santuario de Asclepio y una cita del Evangelio:

Eso era también lo que pretendía decir indirectamente el que escribió, fuera quien fuera, en el pórtico del templo de Epidauro: "Es necesario que sea puro quien entra en un templo que perfuma incienso; mas, pureza es pensar cosas santas." "Y si no os hacéis como estos niños, no entraréis - dice (el Señor) - en el Reino de los Cielos" (Mt 18,3). Así se manifiesta el templo de Dios, sentado sobre el triple fundamento de la fe, la esperanza y la caridad. ${ }^{36}$

El alejandrino cita también la Pítica III del beocio Píndaro, poeta de Asclepio, médico "amante del dinero".

También tienes entre los dioses un médico, no solo un herrero; el médico era amante del dinero, de nombre Asclepio; y te presentaré a su poeta, el beocio Píndaro: "También lo sedujo con magnífica paga, surgiendo oro en sus manos; pero con su mano el hijo de Crono, sacando el aliento de su pecho, lo lanzó rápidamente y un ardiente rayo le infligió la muerte." También Eurípides dice: "En efecto, Zeus es el causante de que matara a mi hijo Asclepio, al arrojarle el rayo a los pechos." Así pues, este yace fulminado en los confines de Cinosuria. ${ }^{37}$

Al señalar la Cinosuria (lit. "Osa Mayor") o Cinuria -región geográfica del suroeste de Arcadia-, Clemente quiere destacar la condición humana de Asclepio. Esta intención es confirmada en un pasaje inmediatamente posterior del Protréptico en el cual cita a los Dioscuros, "hombres destinados a morir si se confía en Homero, quien

\footnotetext{
${ }^{34}$ Ibid. 21, 2, 204.

${ }^{35}$ Justino, Diálogo con Trifón 69, 3, citado por Ruiz Bueno, Padres apologetas griegos, 428.

${ }^{36}$ Clemente de Alejandría, Strómata V, 13, 3-4, 335.

${ }^{37}$ Idem, Protréptico II, 30, 1, 129.
} 
ha dicho: 'A estos los retuvo ya la tierra fecunda, allá en Lacedemonia, en la querida patria." ${ }^{38,39}$

Los Dioscuros, hijos de Leda y de Tíndaro, eran los gemelos mitológicos Cástor y Pólux, quienes -igual que Hercales y al médico Asclepio- son denunciados por Clemente como héroes imaginarios erigidos en salvadores por los griegos, al no conocer al verdadero dios benefactor. ${ }^{40}$ Más adelante, compara a Asclepio con otros benefactores divinizados, como Hermes y Hefesto, de quienes sus mismas patrias, oficios, vidas e incluso sepulturas atestiguan sus respectivas condiciones humanas. ${ }^{41}$

En el ámbito de los escritores latinos, la diatriba más feroz contra Asclepio proviene de Tertuliano, quien supera ampliamente a los apologistas griegos en la intensidad de su crítica.

Se decía que este [Asclepio], tras unos pocos experimentos, había devuelto los muertos a la vida. Este, aunque era hijo de Apolo, era tan hombre como nieto de Júpiter y bisnieto de Saturno (a no ser que se le deba considerar espurio por ser de padre incierto, como deduce el argivo Sócrates ${ }^{42}$ ); este, expuesto al nacer, fue encontrado y alimentado de un modo más indecente que Júpiter, es decir, por una perra, y nadie puede negar que fue un hombre, y [también a este] lo mató un rayo. ¡ El malvado Júpiter Óptimo está aquí de nuevo, impío con su nieto, envidioso de uno tan hábil! Pero Píndaro no ocultó su mérito, pues canta su libídine y su reputada avaricia de ganancias, por la cual aquél llevaba los vivos a la muerte, no los muertos de nuevo a la vida, con el engaño de una medicina muy cara. Se dice también que su madre murió en el mismo momento de su nacimiento ${ }^{43}$, pues con razón dio a luz una bestia, y que subió al cielo por las mismas escaleras. ${ }^{44} \mathrm{Y}$ sin embrago, los atenienses saben sacrificar de este modo a los dioses, pues dan culto a Asclepio y a su madre entre los muertos. ${ }^{45}$

\footnotetext{
${ }^{38}$ Homero, Iliada XVIII, 411.

${ }^{39}$ Ibid., II, 30, 4, 129.

${ }^{40}$ Ibid., II, 26, 7, 121.

${ }^{41}$ Ibid., II, 29, 1, 127.

${ }^{42}$ Se refiere al historiador de Argos quien escribió antes del siglo I a.C.

${ }^{43}$ Según la leyenda más aceptada, Corónide, madre de Asclepio, fue castigada por Apolo por haber mantenido relaciones con un hombre. Al colocarla sobre la pira funeraria, el dios le arrancó del vientre a su hijo Asclepio, quien aún vivía.

${ }^{44}$ Es decir, la pira funeraria.

${ }^{45}$ Tertuliano, $A$ los paganos II, 14, 9-14, 139ss.
} 
Tertuliano pretende destacar el ejercicio deshonesto de la medicina por parte de Asclepio a partir de un texto de Píndaro en Píticas III, 54-59, que el africano cita de manera incorrecta. Reitera esa acusación en otra obra escrita en torno del mismo año 197 y conocida como $A$ los paganos. Por eso leemos en El Apologético:

También uno de los líricos (me refiero a Píndaro) canta a Esculapio, ajusticiado por un rayo a causa de su avaricia, por haber ejercido delictivamente la medicina (medicinam nocenter exercebat). ¡Malvado es Júpiter, ya que suyo es el rayo, impío para con el nieto, envidioso para con el artífice! ${ }^{46}$

También Lactancio se refiere a Asclepio en numerosas ocasiones, entre ellas, aludiendo a su origen vergonzoso por la unión del dios Apolo con la mortal Corónide, hija del rey tesalio Flegias ${ }^{47}$ y cuestionando la sabiduría de Sócrates por haber rogado a sus familiares, al momento de su muerte, el sacrificio de un gallo a este $\operatorname{dios}^{48}$ :

Temió sin duda que Esculapio le acusara de no haber cumplido su voto ante el juez Radamanto. Si hubiese muerto de una enfermedad, yo pensaría que este hombre estaba loco. Pero, como dijo estas cosas estando en sus cabales, el loco es quien piense que era un sabio. ${ }^{49}$

Contrarios a los supuestos intereses mercenarios de este dios, los cristianos, cuyo culto reemplazó al de las divinidades paganas curadoras, se llaman a sí mismos anárgyroi, "no cobradores". ${ }^{50}$

La oposición entre la acción sanadora de Jesús y la de Asclepio era muy conocida en los primeros siglos del cristianismo. Como señala L. Gil Fernández, las curaciones realizadas por Jesús se distinguen de las obradas por Asclepio en ciertos aspectos decisivos:

- Tienen lugar a plena luz, no en la intimidad de una experiencia onírica de incubatio, y se efectúan de modo instantáneo y a la vista de todos; en cambio, cuando la sanación acontece sin la presencia de testigos pesa sobre el enfermo curado la prohibición de divulgarlo.

\footnotetext{
${ }^{46}$ Idem, El apologético 14, 5, 74.

${ }^{47}$ Ver a Lactancio, Instituciones divinas I, 10, 1, 97.

${ }^{48}$ Ver a Platón, “Fedón” 118b, 140.

${ }^{49}$ Lactancio. Instituciones divinas III, 20, 17, 316.

${ }^{50}$ Gil Fernández, “Medicina, religión y magia en el mundo griego”, Capítulo 4, 129.
} 
- $\quad$ Por otra parte, Jesús no demora su epifanía a la manera de Asclepio, que lo hace en reiteradas y a veces fracasadas dormiciones en su templo; tampoco condiciona el éxito de una curación al seguimiento de una dieta o tratamiento, como los que prescribe en los sueños el dios griego.

- Finalmente, muchas de las curaciones de Jesús se caracterizan por la transgresión a costumbres consagradas por la religión oficial y que alcanzan el rango de tabúes socio-religiosos, tales como los de tocar a un impuro o pasar por alto el precepto del descanso sabático. ${ }^{51}$

Orígenes hace eco de esta discusión, escribiendo hacia la mitad del siglo III su refutación al Alèthès Logos del pagano Celso, texto polémico y cargado de profundas críticas contra la nueva fe.

Además, cuando se dice de Asclepio que una gran muchedumbre de griegos y bárbaros confiesa haberlo muchas veces visto, y verlo todavía, no como mero fantasma sino como a él mismo curando, haciendo beneficios y prediciendo lo por venir, Celso nos manda que lo creamos; y de creer en esas cosas, nada tendría que reprocharnos a los fieles de Jesús; mas cuando prestamos crédito a los discípulos de Jesús que vieron sus milagros y muestran patentemente la sinceridad de su conciencia, pues vemos su ingenuidad, en cuanto cabe ver por los escritos una conciencia, Celso nos regala el calificativo de "gentes necias". ${ }^{52}$

El argumento de Orígenes consiste en oponer a Celso multitud de testimonios que el pagano no puede acreditar en favor de Asclepio, además de que muchos de los testigos entre griegos y bárbaros experimentaron curaciones con solo invocar el nombre de Jesús; y tan solo por este medio se han librado de graves accidentes, enajenación, locura y otros males que ni hombres ni démones pudieron curar.

El alejandrino denuncia aquí el carácter oracular de Asclepio, práctica que atribuye a démones que se alimentan de grasas, sangre y perfume de los sacrificios que los griegos ofrecían a Trofonio, Anfiarao y Mopso, a cuyos templos identifica con "cárceles fabricadas por su propio deseo" y con "moradas de démones embusteros". ${ }^{53}$

Y es así que, si Celso dice de veras, como principio universal, que ni un dios ni un hijo de Dios ha bajado ni puede bajar al mundo, échase evidentemente por

\footnotetext{
${ }^{51}$ Idem, "Las curaciones milagrosas", Capítulo 7, 203.

${ }^{52}$ Orígenes, Contra Celso III, 24, 192.

${ }^{53}$ Ibid. VII, 35, 489ss.
} 
tierra la tesis de que haya dioses sobre la tierra, bajados del cielo, ora para dar oráculos sobre lo por venir a los hombres, ora para curarlos por esos mismos oráculos. En consecuencia, ni Apolo Pitio ni Asclepio ni otro dios alguno de los que se creen que hacen todo eso, sería dios bajado del cielo [...]. Sería como un desgraciado a quien no se le concede entrar a la parte de las cosas divinas que allí hay; o, en fin, ni Apolo ni Asclepio, serían dioses de esos que se cree hacen algo sobre la tierra, sino unos démones muy inferiores a los hombres sabios que por su virtud, se remontan a la bóveda del cielo. ${ }^{54,55}$

Por su parte, el monje Teodoreto de Ciro escribe, alrededor de 423 d.C., la conclusión de su tratado apologético Terapéutica de las enfermedades helénicas, la última gran apología del cristianismo antiguo en la que proclama la victoria de Cristo sobre Asclepio. En el libro XII, se refiere a un testimonio de Porfirio, en su obra Contra los cristianos, aparecida en el 270, antes de que Eusebio de Cesarea escribiese su Preparatio evangelica, en la que recoge esa mención del neoplatónico.

Sobre el hecho de que los malos demonios ya no tienen fuerza después de la venida de nuestro Salvador a los hombres, el mismo autor, que entre nosotros ha defendido a los demonios en su escrito contra nosotros lo testimonia con estas palabras: "Ahora se extrañan de que la enfermedad haya dominado la ciudad durante tanto tiempo, cuando Asclepio y los demás dioses no han estado en ella. Hasta que Jesús ha sido venerado, nadie se ha dado cuenta de ninguna ayuda pública de los dioses." Esto es lo que dice, palabra por palabra, Porfirio. Si según esta confesión, nadie ha recibido ayuda pública de los dioses, cuando Jesús es adorado, y cuando ni Asclepio ni ninguno de los demás dioses está presente, ¿¿de dónde procede entonces la creencia de tenerlos por dioses y héroes? ¿Por qué no domina más bien el poder de los dioses y de Asclepio sobre Jesús? Si este es un hombre mortal, como ellos afirman, aunque también ellos dirían que también es un impostor y aquellos son salvadores y dioses, ¿̨por qué motivo todos en masa han huido con el mismo Asclepio, han dado su espalda al mortal y han dejado sometida toda la humanidad futura a alguien que no existe, según ellos? Jesús, después de su muerte, continúa siendo venerado en todos los pueblos diariamente, y así lo demuestra de un modo claro y divino a los que son capaces de ver que existe la vida después de la muerte. ${ }^{56}$

\footnotetext{
${ }^{54}$ Cfr. Platón. Fedro 247b, 396.

${ }^{55}$ Orígenes, Contra Celso V, 2, 332.

${ }^{56}$ Eusebio de Csearea, "Preparatio evangelica" V, 1, 9-13, 201ss. Ver a Théodoret de Cyr, Thérapeutique des maladies helléniques XII, 96-97, 446, 8-20.
} 
Teodoreto de Ciro alude a ciertos intelectuales helenizados cuya reacción anticristiana había encontrado el favor del emperador Juliano. Teodoreto intenta responder con citas tomadas de Porfirio, Jámblico, Juliano y otros, para argumentar contra las críticas del paganismo con sus mismas armas, incluido el tema de la adivinación, estrechamente ligado al de los sueños de incubación de los devotos de Asclepio.

En este sentido, Celso afirma que Asclepio, "mientras cura a los hombres hace el bien y predice el futuro". ${ }^{57}$

Por su parte, Hipólito de Roma -en sus Philosophoumena- dedica un apartado del libro IV, 27-42 a la descripción de las prácticas mágicas, entre las cuales se incluyen los engaños con fuego, referidos especialmente al "ardiente" Asclepio. En IV, 32 registra una invocación de once versos a Asclepio, al que se lo llama mágon prómos, "jefe de los magos". ${ }^{8}$

\section{La suplantación cristiana de los templos paganos}

Durante el episcopado de Teófilo, patriarca de Alejandría (385-412), se inició un proceso violento de erradicación del paganismo bajo la influencia de la política imperial y de los monjes egipcios. Esa campaña culminó en el 391, con la destrucción del Serapeo de Alejandría, uno de los templos paganos más importantes de la Antigüedad. En el mismo se rendía culto a Asclepio junto al de Serapis, Isis, Anubis y Astarté, en una serie de dependencias y santuarios. ${ }^{59}$

Por su parte, los templos de Serapis, en Canopo, y de Isis, cercano al anterior, corrieron la misma suerte. En el templo de Canopo se instaló una comunidad de monjes de San Pacomio, y el de Isis fue transformado en iglesia dedicada a los evangelistas. Pero las acciones de Teófilo no lograron conjurar la pasión de los fieles, quienes continuaban asistiendo al lugar para lograr la curación por parte de la diosa. A pesar de haberse transformado en una iglesia cristiana, se seguía practicando la incubatio y se desplegaban actividades oraculares, como si la misma dynamis divina siguiera apegada al lugar aun cuando había cambiado la deidad tutelar. Como señala Fernández Marcos:

A pesar de tan drásticas medidas, Isis seguía seduciendo a la población de Alejandría y alrededores, que acudía al lugar del santuario transformado en

\footnotetext{
${ }^{57}$ Ver a Orígenes, Contra Celso III, 24, 192 ss.

${ }^{58}$ Nieto Ibáñez, Cristianismo y profecias de Apolo. Los oráculos paganos en la patrística griega (siglos II-V), 88.

${ }^{59}$ Ver a López Salvá, “Isis y Serapis: difusión de su culto en el mundo grecorromano”, 161-192.
} 
iglesia a implorar su protección, consultar su oráculo y sobre todo a obtener un sueño terapéutico por el procedimiento de la incubatio. ${ }^{60}$

Para culminar el proceso de suplantación del culto, el sobrino de Teófilo y sucesor en el episcopado, Cirilo (412-44), dio un paso más osado. Para ello, utilizó un recurso muy extendido en la Iglesia cristiana de la época, el de aducir una revelación a través del sueño, en la cual un ángel le había indicado el lugar de la tumba de Ciro, mártir de existencia dudosa, en la iglesia patriarcal de Alejandría. Hizo excavar en el lugar y encontró unos restos que estaban junto a los de otro cuerpo, que Cirilo atribuyó al de Juan, otro mártir de incierta historicidad. Hizo trasladar los restos con solemnidad y pompa hasta el templo de los evangelistas que Teófilo había construido en Menute e hizo difundir la creencia de que la potencia terapéutica de Isis se había transferido a los nuevos santos tutelares del lugar.

La elección de los santos como la de sus nombres, por parte de Cirilo, no fue casual sino cuidadosamente calculada. Es conocido que Cirilo mantenía profunda rivalidad con Constantinopla, en uno de cuyos santuarios se rendía culto a dos hermanos conocidos como Cosme y Damián, santos que también tenían propiedades terapéuticas. Por tanto, dispuso el par de santos tutelares sobre el modelo de los que eran venerados en Constantinopla, ya que Ciro y Juan comenzaron a ser presentados como hermanos.

El nombre de Ciro (Kyros), supuestamente el mayor de los hermanos, pretendía sustituir al de Isis, diosa protectora del lugar a la que sus fieles invocaban como Kyra, "la Señora". Precisamente, en una de sus homilías, dice Cirilo: "Se llaman Ciro y Juan y en adelante, el pueblo debe invocar a Kyros y no a Kyra." Igual que los demás cristianos de la época, Cirilo creía en la eficacia terapéutica de Isis, pero la misma se adscribía a los demonios, ya que todos los dioses paganos habían sido rebajados a esa categoría por parte de los cristianos.

Se hacía necesario disponer de un santuario en el que se practicara la incubatio, pero bajo la advocación de los nuevos santos. Cirilo, hábil conocedor de los estímulos religiosos de los fieles, consideró oportuno mantener la práctica, reorientándola hacia el poder de los santos tutelares, y al mismo tiempo, combatir frontalmente los cultos paganos.

Los fieles, al carecer del santuario de un mártir, acudían a otros lugares y, aun siendo cristianos, andaban equivocados. Por eso tuvimos que buscar las reliquias de mártires [...]. Vengan pues los que en otro tiempo andaban en el error;

${ }^{60}$ Fernández Marcos, Los Tháumata de Sofronio. Contribución al estudio de la incubatio cristiana, 14-15. 
acérquense al hospital verdadero e insobornable; puesto que ya nadie finge sueños, nadie dice a los que se acercan: "Lo ha dicho la Señora (Kyra): haz esto o aquello." ¿Quiere ser a la vez señora y divinidad poderosa para que se postren ante ella? Entre los démones no hay ni macho ni hembra. Y considerad cuál es su intención: quieren que se les invoque con nombres de mujeres. Así pues, conculcando los cuentos de viejas y las burlas antiguas de los magos, acérquense a los médicos verdaderos que proceden de arriba. ${ }^{61}$

A la información proporcionada por las dos homilías que Cirilo pronunció en Alejandría se suman los datos aportados por los Thaumata o milagros producidos en el santuario de Menute y por el "Encomio o Laudes de los santos Ciro y Juan", ambas obras escritas por Sofronio, obispo de Jerusalén. ${ }^{62}$ Él afirma que, en el momento en que las reliquias de los santos arribaron a Menute, huyeron los demonios que moraban allí: “...después de perseguir al demon arrojándolo de la tierra al inframundo y de llevar en triunfo el trofeo por su huida, mostraron la casa sin habitante."

Asimismo, el relato afirma que Isis fue expulsada del lugar y todos los sacerdotes que oficiaban su culto se convirtieron y fueron bautizados. Se sucedió una serie de milagros que fue completando la suplantación del santuario pagano por el cristiano, y tanto la aldea de Menute como su viejo templo y la estatua de la diosa quedaron sepultados bajo la arena, sin dejar rastros. Isis, quien era considerada en la Antigüedad como protectora de los navegantes, ha cedido esta función ahora a los santos Ciro y Juan, quienes -además de brindar su cuidado a los que se acerquen al puerto de Alejandría- exhibirán también sus facultades terapéuticas. ${ }^{63}$

\section{Consideraciones finales}

Finalmente, podemos afirmar que, entre los primeros cristianos, los conocimientos médicos oscilaban entre la taumaturgia o la magia y las corrientes más intelectualmente elaboradas. La mayoría de creyentes proclamaba la superioridad de Cristo sobre Asclepio, tal como es atestiguado en textos de los padres, quienes denuncian la victoria del Nazareno sobre el dios griego de la medicina. No obstante, eran comunes a paganos y cristianos las celebraciones litúrgicas en el templo.

\footnotetext{
${ }^{61}$ Teja, "De Menute a Abukir. La suplantación cristiana de los ritos de la incubatio en el templo de Isis en Menute", 99-114.

${ }^{62}$ Se tiende a identificar con bastante seguridad al Sofronio autor de los Thaumata y de la Laudatio, con el obispo homónimo que asumió en Jerusalén en 634 y que en 638 acompañó al califa Omar en su entrada triunfal en la ciudad.
}

${ }^{63}$ Teja, "De Menute a Abukir", 103. 
La fiesta en sí es el momento en que se establece una relación significativa entre el individuo y la divinidad, mientras que el santuario pagano o la iglesia cristiana son lugares en los que indistintamente se manifiesta el numen de la deidad sanadora. Es así que ciertos templos cristianos de Oriente, en especial los mencionados aquí, presentan características semejantes a los de Asclepio. Algunas analogías resultan sorprendentes. Por ejemplo, en las dependencias de las iglesias de Constantinopla se destacaba la presencia de baños como en los Asklepieia de Epidauro, Cos, Pérgamo o en los lugares de incubatio de Oropos, Lebena y Paros.

Por otra parte, el tránsito de enfermos requería de un personal que se hiciera cargo de tales dependencias. Mientras en los Asklepieia paganos estos cargos conocidos como dsákaroi y nakóroi eran ejercidos por mujeres, como en el caso de Epidauro, en la iglesia cristiana de Santa Tecla de Seleucia también eran mujeres quienes se ocupaban de estas tareas, si bien hay que reconocer que se trata del único santuario cristiano con personal femenino (parthénoi). El hecho de que la presencia de mujeres asistentes fuese común en los santuarios paganos y excepcional en los templos cristianos, puede deberse a que en los primeros también se rendía culto a divinidades femeninas como Afrodita, Artemisa, Hygéia y Thémis.

Los enfermos que acudían a los Asklepieia centraban su atención en la imagen escultórica del dios, mientras que los que asistían a los templos cristianos lo hacían en las reliquias de los santos mártires. En las iglesias cristianas, un guardián custodiaba estas reliquias y personal especializado -conocido como perikhytai- se encontraba a cargo de los baños. Por el lado de los santuarios paganos, se ha encontrado una inscripción en Apelas, en la que se menciona a un balanéus, cuya misión era semejante a la de los perikhytay de los cristianos.

La práctica de la incubatio predisponía al enfermo para la recepción de la hagiofanía, tarea que en el caso de los templos cristianos se desplegaba por medio de la liturgia, de cánticos, lecturas y oraciones.

En realidad nunca existió una sustitución de Asclepio por Cristo, sino más bien una adaptación de las prácticas rituales de los templos dedicados a Asclepio al nuevo contexto cristiano. Tal adaptación no se produjo de manera inmediata y compulsiva, sino exigió un largo proceso desplegado a lo largo de los primeros siglos y caracterizado principalmente por dos operaciones:

- La primera consistió en el énfasis de los apologistas cristianos en la superioridad de Cristo sobre Asclepio.

- La segunda, en la disposición de dependencias y la realización por parte de las iglesias cristianas de gestos litúrgicos semejantes a las prácticas observadas en los santuarios paganos. 
La cantidad de literatura apologética elaborada con este fin es prueba de la primera de estas dos operaciones, a la vez que de la preocupación que comportaba, para los primeros cristianos, el culto pagano a Asclepio. Las colecciones de milagros de curación recogidas en las iglesias antiguas -especialmente en las del mundo bizantino-, así como la recuperación de los registros de sus oficios litúrgicos, constituyen un elocuente testimonio de la segunda.

\section{Bibliografía}

Arístides, Elio. “Discursos sagrados.” En Discursos V, por Elio Arístides, 161-168; 175-184. Introducciones, traducción y notas de J. M. Cortés Copete. Madrid: Gredos, 1999.

Aristófanes. "Pluto." En Comedias III, por Aristófanes, 411-510. Introducción, traducción y notas de L. M. Macía Aparicio. Madrid: Gredos. 2007.

Burkert, Walter. Religión griega arcaica y clásica. Traducción de Helena Bernabé. Madrid: Abada Editores, 2007.

Clemente de Alejandría. "Protréptico." En Clemente de Alejandría. El Protréptico, por Marcelo Merino Rodríguez, 54-337. Edición bilingüe. Fuentes Patrísticas 21. Madrid: Ciudad Nueva, 2008.

. "Strómata." En Strómata IV-V: Martirio cristiano e investigación sobre Dios, por Clemente de Alejandría. Edición bilingüe griego-español preparada por Marcelo Merino Rodríguez, 306-549. Fuentes Patrísticas 15. Madrid: Ciudad Nueva. 2003.

Cox Miller, Patricia. Los sueños en la antigüedad tardía. Estudios sobre el imaginario de una cultura. Traducción de María Tabuyo y Agustín López. Madrid: Siruela, 1994.

Del Olmo Lete, Gregorio. Mitos y leyendas de Canaán según la tradición de Ugarit. Institución San Jerónimo. Madrid: Cristiandad, 1981.

Dodds, E. R. Paganos y cristianos en una época de angustia. Algunos aspectos de la experiencia religiosa desde Marco Aurelio a Constantino. Madrid: Cristiandad, 1975.

Esquilo. Agamenón. Traducción y notas de B. Perea. Madrid: Gredos, 2006.

Eurípides. "Alcestis." En Eurípides. Tragedias I. Introducciones, traducción y notas de A. Medina González y J. A. López Pérez, 11-59. Madrid: Gredos, 2000.

Eusebio de Csearea. "Preparatio evangelica." En Preparación evangélica I (Libros I-VI). Introducción general de Jesús Ma. Nieto Ibáńez. Traducción y notas por Vicente 
Bécares Botas (Libros I, II y III), Jesús Ma. Nieto Ibáñez (Libros IV, V y VI). Madrid: Biblioteca de Autores Cristianos, 2011.

Fernández Marcos, Natalio. Los Tháumata de Sofronio. Contribución al estudio de la incubatio cristiana. Madrid: CSIC, 1975.

Gil Fernández, Luis. "Las curaciones milagrosas." En En la frontera de lo imposible. Magos, médicos y taumaturgos en el Mediterráneo antiguo en tiempos del Nuevo Testamento, editado por Antonio Piñero, Capítulo 7, 196-215. Córdoba: El Almendro, 2001.

. "Medicina, religión y magia en el mundo griego." En En la frontera de lo imposible. Magos, médicos y taumaturgos en el Mediterráneo antiguo en tiempos del Nuevo Testamento, editado por Antonio Pińero, Capítulo 4, 117-139. Córdoba: El Almendro, 2001.

. Therapeia. La medicina popular en el mundo clásico. Madrid: Tricastela, 1969.

Grimal, Pierre. Diccionario de mitología griega y romana. Buenos Aires-BarcelonaMéxico: Paidós, 2010.

Hanson, J. S. "Dreams and Visions in the Graeco-Roman World and Early Christianity." En Aufstieg und Niedergang der Römanischer Welt, II, 23/2, editado por W. Haase, 1395-1427. Berlin: Water de Gruyter, 1980.

Heródoto. Historia. Introducción de Francisco Adrados. Traducción y notas de Carlos Schraeder. Madrid: Gredos, 2006.

Homero. Ilíada. Traducción de Luis Segallá y Estalella. Introducciones de Pedro Henríquez Ureña y Marta Alesso. Buenos Aires: Losada, 2005.

Kee, Howard Clark. Medicina, milagro y magia en tiempos del Nuevo Testamento. Córdoba: El Almendro, 1992.

Lactancio. Instituciones divinas. Libros I-III. Introducción, traducción y notas de E. Sánchez Salor. Madrid: Gredos, 1990.

López Salvá, Mercedes. "El sueño incubatorio en el cristianismo oriental." Cuadernos de filología clásica 10 (1976): 147-188.

. "Isis y Serapis: difusión de su culto en el mundo grecorromano." En Minerva: revista de filología clásica 6 (1992): 161-192.

. "La medicina sacra en la Antigüedad." Erytheia: revista de estudios bizantinos y neogriegos 20 (1989): 23-45. 
Nieto Ibáñez, Jesús María. Cristianismo y profecías de Apolo. Los oráculos paganos en la patrística griega (siglos II-V). Madrid: Trotta, 2010.

Orígenes. Contra Celso. Introducción, versión y notas por Daniel Ruiz Bueno. Madrid: Biblioteca de Autores Cristianos, 1967.

Pausanias. Descripción de Grecia. Introducción general de J. Gómez Espelosín. Traducción y notas de María Cruz Guerreo Ingelmo. Madrid: Gredos, 2009.

Píndaro. "Píticas." En Himnos triunfales, por Píndaro, 93-147. Traducción y notas de A. Esclasans. Barcelona: Iberia, 1954.

Platón. "Fedón." En Diálogos III, por Platón. Introducción, traducción y notas de C. García Gual, 21-141. Madrid: Gredos, 2006.

. "Fedro." En Diálogos III, por Platón, 305-409. Introducción, traducción y notas de E. Lledó Ińigo. Madrid: Gredos, 2006.

. "República." En Diálogos IV, por Platón, 149-202. Introducción, traducción y notas de C. Eggers Lan. Madrid: Gredos, 2006.

Rivers, William Halse. Medicine, Magic and Religion. Londres: Kegan Paul, 1924.

Ruiz Bueno, Daniel. Padres apologetas griegos (siglo II). Edición bilingüe completa griego-español. Madrid: Biblioteca de Autores Cristianos, 1996.

Siniscalco, Paolo. "Pagani e christiani antichi di fronte all' esperienza di sogni e visioni." En I linguaggi del sogno, por Vittore Branca, Carlo Ossola y Salomon Resnick, 143-163. Firenze: Sansoni, 1984.

Teja, Ramón. "Cultos y ritos terapéuticos cristianos en la hagiografía de Oriente (siglos IV-VI)." En Cristo e Asclepio. Culti terpeutici e taumaturgici nel mondo mediterraneo antico fra cristiani e pagani, editado por E. dal Covolo y G. Sfameni Gasparro, 129-159. Nuova Biblioteca de Scienze Religiose. Roma: LAS, 2008. . "De Menute a Abukir. La suplantación cristiana de los ritos de la incubatio en el templo de Isis en Menute." 'Ilu. Revista de Ciencias de las Religiones XVIII (2007): 99-114.

Théodoret de Cyr. Thérapeutique des maladies hellénique. Texte critique, introduction, traduction et notes de P. Canivet. Sources Chrétiennes, 57. Paris: Cerf, 1958.

Tertuliano. A los paganos. Introducción, traducción y notas de Jerónimo Leal. Biblioteca de Patrística 63. Madrid: Ciudad Nueva. 2004. . El apologético. Introducción, traducción y notas de Julio Andión Marán. Biblioteca de Patrística 38. Madrid: Ciudad Nueva, 1997. 
Vannier, Anne-Marie. "L'image du Christ médecin chez les Pères." En Les péres de l'Église face à la science médicale de leur temps, dirigido por Véronique BoudonMillot y Bernard Pouderon, 525-553. Paris: Beauchesne, 2005.

Virgilio. Eneida. Introducción de Vicente Cristóbal. Traducción y notas de J. de Echave-Sustaeta. Madrid: Gredos, 1997. 